Journal of Engineering and Applied Sciences 14 (Special Issue 6): 9340-9344, 2019

ISSN: 1816-949X

(C) Medwell Journals, 2019

\title{
Some Physical and Chemical Characteristic of Dust Falling on Kerbela City, Iraq
}

\author{
${ }^{1}$ Asaad Sh. M. Alhesnawi, ${ }^{2}$ Ibrahim M. Alsalman and ${ }^{1}$ Najem Abd. Najem \\ ${ }^{1}$ Department of Biology, College of Education for Pure Sciences, University of Kerbala, Kerbala, Iraq \\ ${ }^{2}$ Department of Biology, College of Education for Pure Sciences, \\ Ibn Al-Haitham University of Baghdad, Baghdad, Iraq \\ asaad.shaheed@gmail.com
}

\begin{abstract}
The study was conducted during the period from March 2017 to February 2018 at three locations rural, urban and industrial to monitoring deposition of dust on monthly basis in Kerbala, Iraq. The results of this study revealed that the rate of dust falling ranged $9.66-96.04 \mathrm{~g} / \mathrm{m}^{2}$ with average $36.47 \mathrm{~g} / \mathrm{m}^{2}$ in the rural and areas industrial, respectively. The morphological analysis of dust using the scanning electron microscope showed that the dust particles are not homogeneous, particularly the urban area, most of which are of different and irregular shapes and the sizes of dust particles ranged from 13.22-30.80 $\mu \mathrm{m}$. The 16 elements in dust were found using energy dispersive $\mathrm{x}$-ray analysis five of them were heavy metals $(\mathrm{Cu}, \mathrm{Cr}, \mathrm{Ni}, \mathrm{Cd}$ and $\mathrm{Pb})$. X-ray diffraction analysis showed that calcite (42.6\%) and quartz (26.1\%) were the dominant minerals in the dust. It appears from the collection and analysis of the results that the sites of study have a significant effect on the concentration, shapes, sizes and contents of dust particles.
\end{abstract}

Key words: Dust fall, minerals, particulate morphology, heavy metals, urban area, scanning electrons

\section{INTRODUCTION}

Air pollution is a major challenge to the urban environment which is steadily increasing due to urban expansion and the decline of green areas. Particulate Matters (PM) are a major air pollutants, according to the Environmental Protection Agency (EPA), an important indicator of ambient air quality and its concentration in the air depends on sources of emission and metrological conditions (Qari and Hassan, 2017). Dust is the particulate matter that range in size from $1 \sim 75 \mu \mathrm{m}$. Recently, researches have been focused on large particles because of their physical and chemical properties. These particles contain many heavy metals, Polycyclic Aromatic Hydrocarbons (PAHs) and pesticides because of their ability to adsorb these pollutants on their surfaces. By this way, many pollutants are transported to remote areas (Al-Dabbas et al., 2011; Al-Awadhi and AlShuaibi, 2013). Dust has many effects on geochemical cycles, ecosystems and the environment as well as negatively affects public health (Harrison et al., 1997; Jickells et al., 2005; Lawrence and Neff, 2009). Many epidemiological studies have shown an increase in deaths, respiratory and cardiovascular diseases as well as allergies. High dust concentrations in the air or dust storms have been associated with the number of patients entering hospitals (Katsouyanni et al., 2001; Fuzzi et al., 2015). Iraq is one of the most affected countries in the Middle East by dust and dust storms due to increased desertification as a result of drought and erosion (Sissakian et al., 2013). Among the most affected provinces is Kerbala which is exposed to dusty events throughout the year due to its proximity to Western Plateau as well as the increase in industrial activities, traffic and urban expansion (Alhesnawi et al., 2018). Despite, the environmental importance of knowledge of the properties and contents of deposition dust, only limited and inadequate studies were conducted. Therefore, this study was designed to estimate the amount of dust falling and to know some of its chemical and physical properties.

\section{MATERIALS AND METHODS}

Study area: The province of Kerbala is located in the Middle Euphrates region of Iraq on the edge of the desert of the Western Desert. The province is located at a latitude of $44^{\circ}$ and $40 \mathrm{~min}$ and at a latitude of $33^{\circ}$ and $31 \mathrm{~min}$ (Fig. 1). The area of the province is $\left(5034 \mathrm{~km}^{2}\right)$ representing $1.14 \%$ of the area of Iraq $\left(438317 \mathrm{~km}^{2}\right)$.

Corresponding Author: Asaad Sh. M. Alhesnawi, Department of Biology, College of Education for Pure Sciences, University of Kerbala, Kerbala, Iraq, asaad.shaheed@gmail.com 


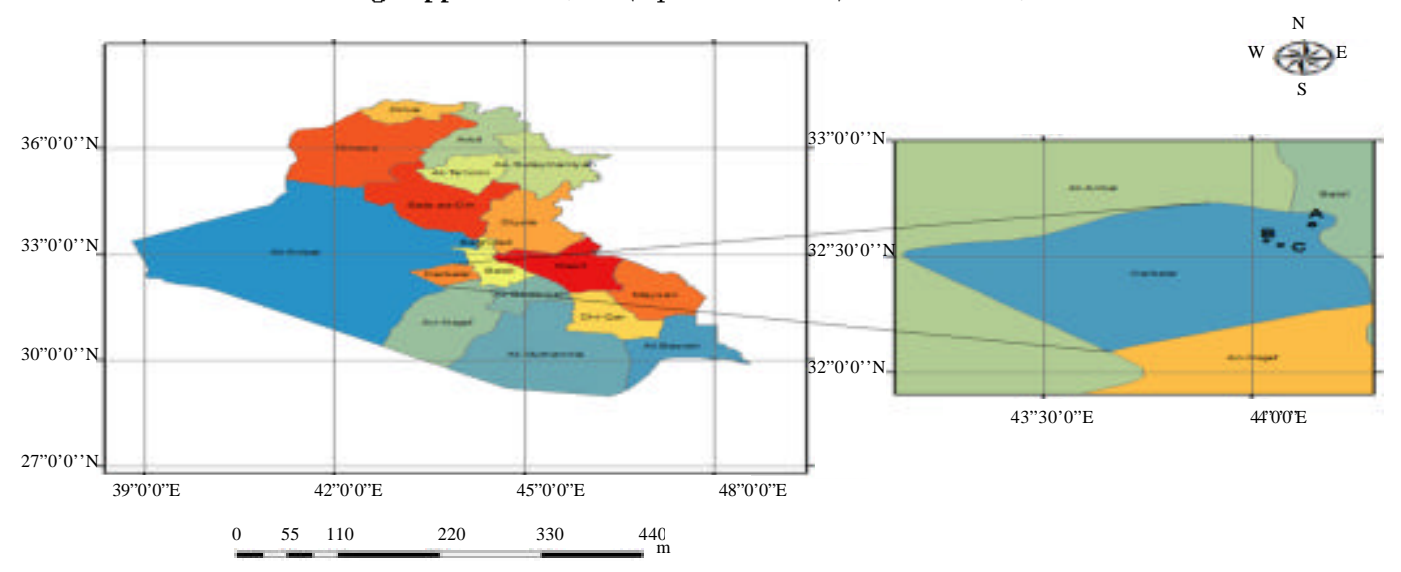

Fig. 1: Rural, urban and industrial study areas

Climate: Temperatures range from $5^{\circ} \mathrm{C}$ in January to $45^{\circ} \mathrm{C}$ in July and average was $25^{\circ} \mathrm{C}$. The governorate is within the $100 \mathrm{~mm}$ rain line within the dry region. The prevailing wind is the Northwest wind, followed by the Western wind.

Samples collection: A sample of dust fall was collected from three sites selected in Kerbala Governorate the first was rural area (N $\left.32^{\circ} 39^{\prime} 33.25^{\prime \prime}, \mathrm{E} 44^{\circ} 8^{\prime} 54.59^{\prime \prime}\right)$, the second was urban area (N 32 36'48.09', E 44'1'56.26') and last

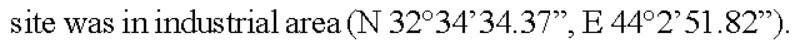
The samples were collected monthly by three replicates from each site from March, 2017 to February, 2018.

Dust fall concentration measurement: To estimate the amount of deposited dust, the described method was followed by Al-Awadhi and AlShuaibi (2013) and the data were expressed as $\mathrm{g} / \mathrm{m}^{2}$ for month (Zhao et al., 2010). Climate data were obtained from Kerbala meteorological station.

SEM and EDS analysis: Scanning Electron Microscope (SEM)/Energy Dispersive X-ray Analysis (EDS) determined the particle morphology and chemical composition. Dust particle sizes were measured using Image-J Software based electron microscope images $(\mathrm{n}=500)$.

X-Ray Diffraction (XRD): Minerals have been identified using X-ray diffraction technique (Bruker D2 Phaser) with $\mathrm{Cu}-\mathrm{Ka}$ radiation at the Faculty of Science, University of Baghdad.

\section{RESULTS AND DISCUSSION}

Dust fall concentration: The highest rate of dust was found in the industrial area followed by urban and rural
Table 1: Correlation coefficient analysis between dust fall concentration and metrological factors

\begin{tabular}{lcc}
\hline Parameters & $\mathrm{r}$ & $\mathrm{p}$-values \\
\hline Temperature (C) & 0.259 & 0.007 \\
Humidity (\%) & -0.265 & 0.006 \\
Rain $(\mathrm{mm})$ & -0.184 & 0.057 \\
Wind Speed $\left(\mathrm{m}^{-1} \mathrm{sec}\right)$ & 0.456 & 0.000 \\
\hline
\end{tabular}

areas, respectively. Palm trees in the rural area play an important role in reducing the amount of dust falling as well as the rise of buildings in urban areas. The results showed that the highest rate of dust in the industrial site was $96.04 \mathrm{~g} / \mathrm{m}^{2}$ in March while the lowest rate in the rural site was $9.66 \mathrm{~g} / \mathrm{m}^{2}$ during February with average deposition rate of $36.47 \mathrm{~g} / \mathrm{m}^{2}$ (Fig. 2). The increase in dust concentrations during the Spring months is due to the high impact of dust storms that coincide annually with these months. The results showed an increase in concentrations of dust falling in the Summer months compared to Winter. This is due to the role of climatic factors in increasing or decreasing dust (Biglari et al., 2017; Malakootian et al., 2013). The role of climatic factors are confirmed by the analysis of the coefficient of correlation between dust and climatic factors. A positive correlation was found between the falling dust and the temperature. In other words, the increase in these factors increases the amount of dust falling. In contrast, a negative correlation was found with relative humidity (Table 1).

Sizes of falling dust: The results showed a difference in dust particles. The highest rate was $30.80 \mu \mathrm{m}$ in the industrial area during the autumn season while the lowest rate was $13.22 \mu \mathrm{m}$ at the urban site during the Winter with average was $19.94 \mu \mathrm{m}$ (Fig. 3). The difference in the size of the dust particles is due to the impact of the site and climatic factors, the most important of which is the wind speed. The analysis of dust sizes shows that the Kerbala 
Table 2: Weight percentage of elements in the dust falling within the study sites

\begin{tabular}{|c|c|c|c|c|c|c|c|c|c|c|c|c|}
\hline \multirow[b]{3}{*}{ Elements } & \multicolumn{12}{|l|}{ Sites } \\
\hline & \multicolumn{4}{|l|}{ Rural } & \multicolumn{4}{|l|}{ Urban } & \multicolumn{4}{|c|}{ Industrial } \\
\hline & Mean & $\mathrm{SD}$ & Min. & Max. & Mean & $\mathrm{SD}$ & Min. & Max. & Mean & $\mathrm{SD}$ & Min. & Max. \\
\hline $\mathrm{C}$ & 23.35 & 7.47 & 12.10 & 40.49 & 24.95 & 18.37 & 8.37 & 67.77 & 30.55 & 16.32 & 13.72 & 68.28 \\
\hline $\mathrm{O}$ & 39.10 & 9.81 & 15.56 & 51.20 & 42.06 & 7.68 & 23.25 & 50.20 & 39.12 & 8.86 & 21.25 & 49.06 \\
\hline $\mathrm{Na}$ & 0.80 & 0.38 & 0.23 & 1.30 & 0.76 & 0.53 & 0.36 & 2.25 & 0.63 & 0.77 & 0.00 & 2.61 \\
\hline $\mathrm{Mg}$ & 1.84 & 0.73 & 0.89 & 2.69 & 1.48 & 0.80 & 0.28 & 3.03 & 1.46 & 0.68 & 0.25 & 2.54 \\
\hline $\mathrm{Al}$ & 3.27 & 0.89 & 1.51 & 4.07 & 2.57 & 1.33 & 0.54 & 5.12 & 2.38 & 1.04 & 0.45 & 3.97 \\
\hline $\mathrm{Si}$ & 9.77 & 3.41 & 4.89 & 18.77 & 8.84 & 3.72 & 1.78 & 13.65 & 8.22 & 3.80 & 1.56 & 14.41 \\
\hline $\mathrm{s}$ & 1.68 & 0.95 & 0.64 & 3.60 & 1.76 & 0.88 & 0.41 & 3.57 & 2.34 & 1.81 & 0.20 & 6.89 \\
\hline $\mathrm{Cl}$ & 1.16 & 0.59 & 0.52 & 2.56 & 1.51 & 2.46 & 0.12 & 8.23 & 1.22 & 1.09 & 0.00 & 4.00 \\
\hline $\mathrm{K}$ & 1.63 & 0.68 & 0.80 & 3.43 & 0.89 & 0.50 & 0.24 & 2.18 & 0.79 & 0.53 & 0.00 & 1.58 \\
\hline $\mathrm{Ca}$ & 10.82 & 3.48 & 8.02 & 20.39 & 9.63 & 5.01 & 3.23 & 20.55 & 8.95 & 3.56 & 2.74 & 13.89 \\
\hline $\mathrm{Cr}$ & 0.14 & 0.17 & 0.00 & 0.51 & 0.21 & 0.11 & 0.05 & 0.41 & 0.36 & 0.67 & 0.00 & 2.37 \\
\hline $\mathrm{Ti}$ & 0.24 & 0.15 & 0.00 & 0.46 & 0.06 & 0.06 & 0.00 & 0.20 & 0.10 & 0.14 & 0.00 & 0.42 \\
\hline $\mathrm{Fe}$ & 4.81 & 0.72 & 3.64 & 6.06 & 3.84 & 1.80 & 1.00 & 7.49 & 3.86 & 1.46 & 1.20 & 5.94 \\
\hline $\mathrm{Ni}$ & 0.38 & 0.58 & 0.00 & 2.05 & 0.79 & 0.73 & 0.08 & 2.62 & 0.46 & 0.41 & 0.00 & 1.20 \\
\hline $\mathrm{Pb}$ & 0.39 & 0.50 & 0.00 & 1.35 & 0.32 & 0.25 & 0.00 & 0.90 & 0.53 & 0.44 & 0.02 & 1.55 \\
\hline $\mathrm{Cd}$ & 0.60 & 0.78 & 0.00 & 2.49 & 0.12 & 0.13 & 0.00 & 0.34 & 0.26 & 0.32 & 0.00 & 0.95 \\
\hline
\end{tabular}

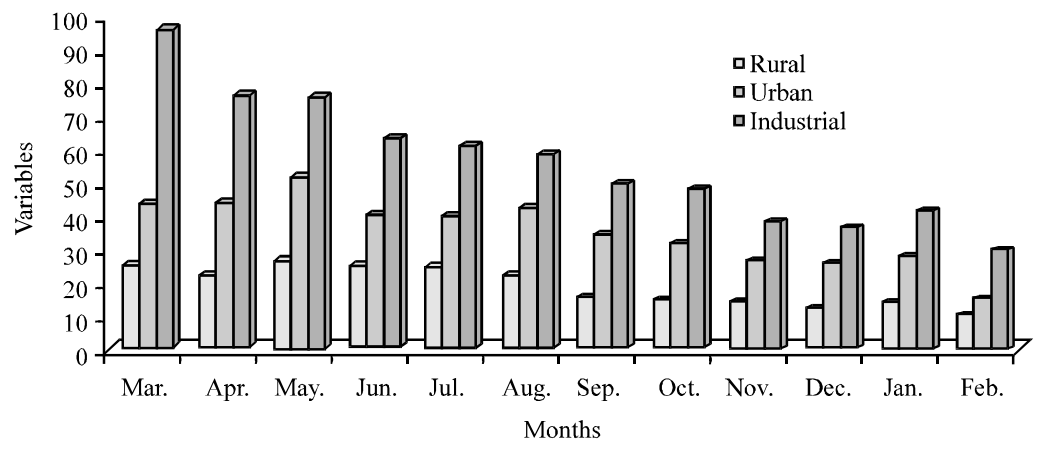

Fig. 2: Monthly variations of dust falling on the province of Kerbala within the study areas: total dustfall $\mathrm{g} / \mathrm{m}^{2}$

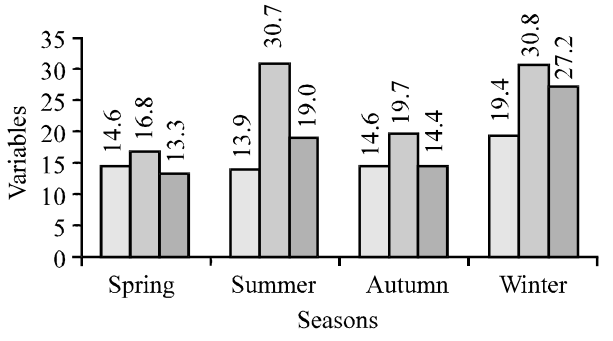

Fig. 3: Average of dust fall particle sizes during seasons and locations: dust fall size $(\mu \mathrm{m})$

is significantly affected by local activities and soil erosion much more than the effect of the mobile sand dunes coming from Western Sahara. Some studies have suggested that dust particles of $<50$ microns are sourced from local sites and sedimentation processes of suspended air particles rather than mobile sand dunes while particle sources larger than 100 microns are sand dunes (Mori et al., 2002; Wang et al., 2005). More importantly that the dust in the respirable size range is harmful to human health (Bian and Zender, 2003; Guthrie and Mossman, 1993).

Morphology of dust fall: The results of the analysis by the electron microscope showed significant changes in the shapes and sizes of the dust particles in the study sites during the Spring and Autumn(Fig. 4). These changes can be due to the impact of the site because the particles of falling dust are large and often settle close to their sources. Attribute the dust particles falling in the urban site were very different and heterogeneous compared to other sites and the various activities in the city, traffic, the increase of vehicles, building construction and workshops. The morphology of particles produced from natural sources are have solid and irregular shapes while that particles from anthropogenic sources are liquid or solid with variable morphology. The spherical shape of particles as result to the secondary reactions and transportation in atmosphere (Buseck et al., 2000; Li and Shao, 2009). 

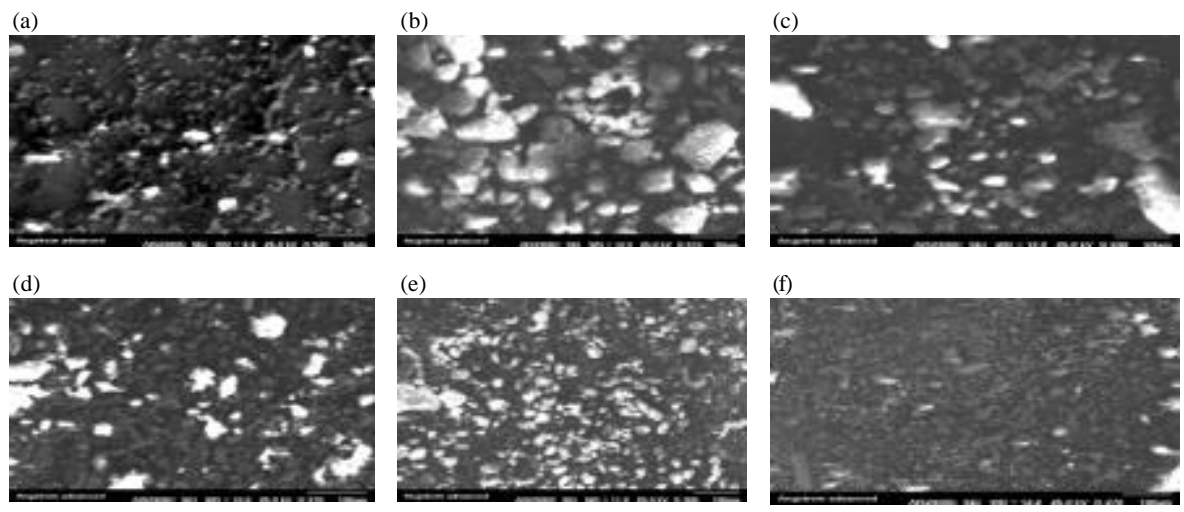

Fig. 4: SEM analysis for dust particles shown different changes in size and shapes: a) Rural/Autumn; b) Urban/Autumn; c) Industrial/Autumn; d) Rural/Spring; e) Urban/Spring and f) Industrial/Spring

Table 3: The mineral composition of the falling dust in the study sites

\begin{tabular}{|c|c|c|c|c|c|c|c|}
\hline \multirow[b]{2}{*}{ Minerals } & \multicolumn{3}{|l|}{ Sites } & \multirow[b]{2}{*}{ Mean } & \multirow[b]{2}{*}{ SD } & \multirow[b]{2}{*}{ Min. } & \multirow[b]{2}{*}{ Max. } \\
\hline & Rural & Urban & Industrial & & & & \\
\hline Calcite & 40.8 & 49.4 & 37.7 & 42.6 & 6.1 & 37.7 & 49.4 \\
\hline Quartz & 23.0 & 17.6 & 37.8 & 26.1 & 10.5 & 17.6 & 37.8 \\
\hline Albite & 8.4 & 0.0 & 9.9 & 6.1 & 5.3 & 0.0 & 9.9 \\
\hline Illite & 6.9 & 0.8 & 4.3 & 4.0 & 3.1 & 0.8 & 6.9 \\
\hline Gypsum & 5.9 & 19.2 & 2.8 & 9.3 & 8.7 & 2.8 & 19.2 \\
\hline Dolomite & 4.2 & 0.0 & 3.0 & 2.4 & 2.2 & 0.0 & 4.2 \\
\hline Paly gorskite & 4.1 & 6.2 & 2.3 & 4.2 & 2.0 & 2.3 & 6.2 \\
\hline Kaolinite & 6.6 & 4.7 & 2.2 & 4.5 & 2.2 & 2.2 & 6.6 \\
\hline Halite & 0.0 & 2.1 & 0.0 & 0.7 & 1.2 & 0.0 & 2.1 \\
\hline
\end{tabular}

Chemical composition of dust fall by EDS analysis: As shown in Table 2, 16 elements were found in the falling dust particles in which the oxygen element was dominant and follows the trend as $\mathrm{C}>\mathrm{Ca}>\mathrm{Si}>\mathrm{Fe}>\mathrm{Al}>\mathrm{S}>\mathrm{K}>\mathrm{Mg}>\mathrm{Cl}>$ $\mathrm{Cd}>\mathrm{Na}>\mathrm{Pb}>\mathrm{Ni}>\mathrm{Ti}$. From these elements were found five heavy metals $(\mathrm{Cu}, \mathrm{Cr}, \mathrm{Ni}, \mathrm{Cd}$ and $\mathrm{Pb})$ that have hazardous toxicity to health and the ecosystem (Tchounwou et al., 2012; Suvarapu and Baek, 2016). The presence of changes in the weight percentage of the elements within the sites may be due to the geochemical processes of each site in addition to the local activities that contribute to the increase of a certain element at another expense (Hindy et al., 2018). The presence of elements $\mathrm{Si}, \mathrm{Al}, \mathrm{Fe}$, $\mathrm{Ca}, \mathrm{K}$ and $\mathrm{Mg}$ can be attributed to the abundance of clay minerals carbonates (Miler, 2014). While the presence of heavy metals is due to industrial activities, vehicle exhausts and other different human activities (Ram et al., 2014).

$\mathrm{X}$-ray diffraction analysis of dust fall: The mineral composition of the falling dust was identified as shown in Table 3. The highest percentage of minerals was calcite followed by quartz, gypsum, albite, kaolinite, palygorskite, illite, dolomite and halite. The difference in the ratio of minerals between sites it may be due to impact of the activities variation of each site. The abundance of calcite in the urban area is associated with pollution from cement dust or clay-rich soils. The results show presence of clay minerals for the different sites were illite, kaolinite and palygorskite. The presence of kaolinite and palygorskite among the clay minerals reflects the semi-arid and arid climatic conditions (Al-Dabbas et al., 2011). The results were in agreement with (Al-Dabbas et al., 2011; Al-Awadhi and AlShuaibi, 2013; Hindy et al., 2018; Ram et al., 2014).

\section{CONCLUSION}

The study of the physical and chemical properties of dust revealed that most of its sources were local sources directly affected by on-site activities. The rise of dust concentrations and its containment of clay minerals clearly reflect the state of drought in the country.

The particles of falling dust are very dangerous particles to human health because of their small sizes that can reach the upper parts of the respiratory system and contain heavy metals carcinogenic. 


\section{J. Eng. Applied Sci., 14 (Special Issue 6): 9340-9344, 2019}

\section{REFERENCES}

Al-Awadhi, J.M. and A.A. AlShuaibi, 2013. Dust fallout in Kuwait city: Deposition and characterization. Sci. Total Environ., 461: 139-148.

Al-Dabbas, M., M.A. Abbas and R. Al-Khafaji, 2011. The mineralogical and micro-organisms effects of regional dust storms over Middle. Intl. J. Water Resou. Arid Env., 1: 129-141.

Alhesnawi, A.S.M., I.M. Alsalman and N.A. Najem, 2018. Evaluation of air pollution tolerance index of some plants species in Kerbala city, Iraq. J. Pharm. Sci. Res., 10: 1386-1390.

Bian, H. and C.S. Zender, 2003. Mineral dust and global tropospheric chemistry: Relative roles of photolysis and heterogeneous uptake. J. Geophys. Res. Atmos., 108: 1-14.

Biglari, H., S. Geravandi, M.J. Mohammadi, E.J. Porazmey and R.Z. Chuturkova et al., 2017. Relationship between air particulate matter and meteorological parameters. Fresenius Environ. Bull., 26: 4047-4056.

Buseck, P.R., D.J. Jacob, M. Posfai, J. Li and J.R. Anderson, 2000. Minerals in the air: An environmental perspective. Intl. Geol. Rev., 42: 577-593.

Fuzzi, S., U. Baltensperger, K. Carslaw, S. Decesari and H.D. van der Gon et al., 2015. Particulate matter, air quality and climate: Lessons learned and future needs. Atmos. Chem. Phys., 15: 8217-8299.

Guthrie Jr., G.D. and B.T. Mossman, 1993. Merging the geological and biological sciences: An integrated approach to the study of mineral-induced pulmonary diseases. Proceedings of the International Conference on Health Effects of Mineral Dusts (CONF-9310406- Vol. 28), October 22-24, 1993, Mineralogical Society of America, Washington, DC., USA., pp: 1-584.

Harrison, R.M., D.J.T. Smith, C.A. Piou and L.M. Castro, 1997. Comparative receptor modelling study of airborne particulate pollutants in Birmingham (United Kingdom), Coimbra (Portugal) and Lahore (Pakistan). Atmos. Environ., 31: 3309-3321.

Hindy, K.T., A.R. Baghdady, M.F. Howari and A.S. Abdelmaksoud, 2018. A qualitative study of airborne minerals and associated organic compounds in southeast of Cairo, Egypt. Intl. J. Environ. Res. Publ. Health, 15: 1-16.

Jickells, T.D., Z.S. An, K.K. Andersen, A.R. Baker and G. Bergametti et al., 2005. Global iron connections between desert dust, ocean biogeochemistry and climate. Sci., 308: 67-71.
Katsouyanni, K., G. Touloumi, E. Samoli, A. Gryparis and A. Le Tertre et al., 2001. Confounding and effect modification in the short-term effects of ambient particles on total mortality: Results from 29 European cities within the APHEA2 project. Epidemiology, 12: $521-531$

Lawrence, C.R. and J.C. Neff, 2009. The contemporary physical and chemical flux of aeolian dust: A synthesis of direct measurements of dust deposition. Chem. Geol., 267: 46-63.

Li, W.J. and L.Y. Shao, 2009. Observation of nitrate coatings on atmospheric mineral dust particles. Atmospheric Chem. Phys., 9: 1863-1871.

Malakootian, M., M. Ghiasseddin, H. Akbari and N.A.J.H. Fard, 2013. Urban dust fall concentration and its properties in Kerman City, Iran. Health Scope, 1: 192-198.

Miler, M., 2014. SEM/EDS characterisation of dusty deposits in precipitation and assessment of their origin. Geologija, 57: 5-14.

Mori, I., M. Nishikawa, H. Quan and M. Morita, 2002. Estimation of the concentration and chemical composition of kosa aerosols at their origin. Atmos. Environ., 36: 4569-4575.

Qari, H.A. and I.A. Hassan, 2017. Bioaccumulation of $\mathrm{PAHs}$ in Padina boryana Alga Collected from a Contaminated Site on the Red Sea, Saudi Arabia. Pol. J. Environ. Stud., 26: 435-439.

Ram, S.S., R.V. Kumar, P. Chaudhuri, S. Chanda and S.C. Santra et al., 2014. Physico-chemical characterization of street dust and re-suspended dust on plant canopies: An approach for finger printing the urban environment. Ecol. Indic., 36: 334-338.

Sissakian, V., N. Al-Ansari and S. Knutsson, 2013. Sand and dust storm events in Iraq. J. Nat. Sci., 5: 1084-1094.

Suvarapu, L.N. and S.O. Baek, 2016. Determination of heavy metals in the ambient atmosphere: A review. Toxicol. Ind. Health, 33: 79-96.

Tchounwou, P.B., C.G. Yedjou, A.K. Patlolla and D.J. Sutton, 2012. Heavy Metal Toxicity and the Environment. In: Molecular, Clinical and Environmental Toxicology, Volume 3: Environmental Toxicology, Luch, A. (Ed.). Springer, Basel, Switzerland,ISBN-13: 978-3-7643-8340-4,pp: 133-164.

Wang, X., Z. Dong, P. Yan, Z. Yang and Z. Hu, 2005. Surface sample collection and dust source analysis in northwestern China. Catena, 59: 35-53.

Zhao, J., P.A. Peng, J. Song, S. Ma and G. Sheng et al., 2010. Research on flux of dry atmospheric falling dust and its characterization in a subtropical city, Guangzhou, South China. Air Qual. Atmos. Health, 3: $139-147$. 